\title{
Drawbacks of a Delisting from a Sustainability Index: An Empirical
} Analysis

\author{
Angeloantonio Russo ${ }^{1}$ \& Massimo Mariani ${ }^{1}$ \\ ${ }^{1}$ Department of Management, LUM University, Casamassima (BA), Italy \\ Correspondence: Angeloantonio Russo, PhD, Associate Professor of Management, Department of Management, \\ LUM University, S.S. 100 Km 18, 70010, Casamassima (BA), Italy. Tel: 39-80-697-8111. E-mail: russo@lum.it
}

Received: October 1, 2013

Accepted: October 21, 2013

Online Published: November 7, 2013

doi:10.5430/ijba.v4n6p29

URL: http://dx.doi.org/10.5430/ijba.v4n6p29

\begin{abstract}
All businesses must balance a focus on profits with a focus on ethics. In today's business world, investors are paying an increasing amount of attention to companies' commitments to corporate sustainability (CS). In order to enhance the credibility of their CS investments, large companies often seek listings in the major sustainability indexes. However, what are the drawbacks of being delisted from such indexes? This paper aims to determine the impact of such a delisting on firm performance. Our sample covers firms included in and deleted from the FTSE4Good sustainability index from 2008 to 2011. The results reveal a negative relationship between firm performance and a delisting. This relationship is explained in terms of how performance is negatively affected by firms' scores on different sustainability criteria. In addition, a listing on one of the three main stock exchanges is found to positively moderate the negative relationship between being delisted from a sustainability index and stock-market reactions.
\end{abstract}

Keywords: corporate sustainability, delisting, firm value, socially responsible investing, sustainability index

\section{Introduction}

All businesses must balance a focus on profits with a focus on ethics, especially if they wish to remain competitive (Lo \& Sheu, 2007). In the last decade, numerous business scandals have been the result of public opinions on sustainability. Therefore, many companies actively work to make investors aware why of a focus on sustainability must be part of a firm's day-to-day activities, and an increasing number of companies are committed to credibly signaling leadership in the sustainability arena.

Although most companies engage in sustainability activities in order to bolster their reputations, the early leaders in this field were seeking ways to differentiate themselves from their competitors. This desire, in turn, created an opportunity for external parties to develop an instrument to track firms' performance in terms of corporate sustainability (CS), which would make information on that performance available to investors. Today, socially responsible investing (SRI) represents the youngest financial-services industry that investors can exploit to implement their investment strategies. SRI's modern roots originate from the 1960s (Schueth, 2003). Although literature in this field is growing, additional research is needed on the effect of the adoption of CS strategies (Sparkes \& Cowton, 2004) by both firms and investors. Notably, Fowler and Hope (2007) show that companies pursuing this objective typically seek inclusion in a recognized sustainability index.

On the basis of previous literature investigating the relationship between CS orientation and a firm's financial performance, this paper focuses on the effect of being delisted from a sustainability index. In this regard, several research questions are examined. For example, after a company achieves the objective of being listed in a sustainability index, how is the firm impacted by a delisting from this index? What is the relationship, if any, between a firm's market value and its stock returns, and delisting? Does inclusion on a country-specific stock exchange influence the relationship between delisting and firm performance?

For our analyses, we used a sample of 151 firms that were initially included in and then delisted from the FTSE4Good Global Index sustainability index from 2008 to 2011. In this study, firm performance is measured in terms of market value (Tobin's Q) and stock-market reactions (Cumulative Average Abnormal Returns, CAAR). Given the nature of the variables included in the analysis, feasible generalized least square (FGLS) models have been used. Our results indicate that the market is responsive to corporate investments in sustainability and that delisting 
from a sustainability index generates a signaling mechanism that results in a reduction of value for the company in question. This finding has several implications for researchers and practitioners.

This paper is structured as follows. We begin by defining sustainability and examining its connection with corporate reputation, with a special emphasis on listed corporations. The relationships among CS, reputation, and firm performance are then analyzed in order to justify companies' decisions to commit resources to the goal of obtaining a listing in a recognized sustainability index. We then present our data and methodology before discussing our empirical results and conclusions.

\section{Theoretical Background and Hypotheses}

\subsection{Defining a Sustainability-Oriented Strategic Approach}

Lo and Sheu (2007) demonstrate that investments in sustainability are not just wasted costs for a company. In fact, such investments can be beneficial for value growth. This is one reason why firms face rising expectations related to environmental and social performance. In fact, since the 1960s, external pressures to engage in sustainable development and CS have been rising.

Today, many companies seek new business models that will enable them to reduce their carbon emissions, diminish their environmental footprints, and make a generally positive contribution to the community (McDonough, William, \& Braungart, 2002). As a result, sustainability is no longer viewed as belonging at the bottom of pyramid. Rather, it is increasingly viewed as a crucial asset for companies wishing to be competitive on the market (Roberts \& Dowling, 2002). This proactive attitude towards CS makes firms' top-management teams aware of how social responsibility and the pursuit of sustainable development can be a way to create a competitive sustainable advantage.

Firms are increasing their investments in sustainable projects in order to bolster their reputations, thereby protecting their social licenses to operate (Russo \& Tencati, 2009). However, any investment a firm makes must also be profit oriented. Furthermore, the relationships among CS, reputation, and firm value must be analyzed in order to justify the way firms manage their relationships with specific stakeholders, such as those in the market for control. Within this context, a listing in a recognized sustainability index can be value generating for firms. Furthermore, those firms that were the early leaders in the sustainability arena are experiencing a kind of "Red Queen" effect, as they need to continually find ways to differentiate themselves (Robinson, Kleffner, \& Bertels, 2011).

Terms such as corporate sustainability, corporate social responsibility (CSR), and sustainable development relate to the triple bottom line in which corporations focus on economic, social, and environmental values. In other words, they seek to achieve a balanced focus on people, the planet, and profits (Elkington, 2004). In 1997, Elkington claimed the necessity of firms adding other variables in order to define company value. These variables are the environmental and social elements that a company has to consider in order to understand whether it is adding or destroying value. Elkington (1997) also stated that sustainable capitalism must be based on seven drivers: markets, value, transparency, technology life-cycle, partnership, time, and corporate governance. Elkington's work served as the basis for the development of theory on the triple bottom line. Today, the concept of CS includes business strategy, leadership and management development, finance, environmental issues, ethics, human resource management, diversity, industry, and community issues, health and safety, corporate governance and labor relations (Fisher, 2010).

Despite the discussion in the extant literature, distinguishing between the concepts of CS and CSR can be difficult. Several views have been offered on this issue. The first perspective implies that these two terms are similar but suggests that they have different focuses. In fact, CSR scholars tend to relate the relevancy of environmental issues to the degree of benefits that can be offered to people, while CS scholars focus on environmental subjects in their own right, independent of benefits for humanity (Montiel, 2008). The second perspective suggests that CS is related to the role of corporations as human-oriented agents because it aims to sustain corporations as viable business entities, while CSR is connected to the role of corporations as a form of communion between humans and the environment (van Marrewijk, 2003). The third perspectives simply defines CSR as a corporate responsibility, which is part of CS (Panapanaan, Linnanen, Karvonen, \& Phan, 2003).

\subsection{Corporate Sustainability and Firm Value}

While the literature recognizes a difference between CSR and CS, the suggestion of a relationship between CS and firm value is relatively new. Furthermore, extant research on this subject tends to consider the link from an investment perspective (Wai Kong Cheung, 2011).

Several researchers have investigated the relationship between corporate sustainability performance (CSP) and corporate financial performance (CFP) (Perrini, Russo, Tencati \& Vurro, 2011). These studies find a positive, 
although sometimes weak, relationship between the two. In a meta-analysis of 30 years of CSP/CFP studies, Orlitzky and Benjamin (2001) determine that CSP and CFP are positively correlated. This seemingly positive correlation captured the attention of many important business people, who started to justify investments in CS as a way of enhancing corporate reputation and firm value (Sen \& Bhattacharya, 2001).

The costs associated with acquiring a good reputation on the CS side are offset by reductions in other costs (Nygaard and Russo, 2008; Pogutz et al., 2009). According to this perspective, committing resources to socially responsible actions can have a positive impact on firm results. For example, external stakeholders (e.g., governments or local communities) who care about the environment may accept less strict environmental regulation if they are convinced of a firm's commitment to sustainability. In contrast, non-responsible actions can be one of the most common reasons for making negative claims about current environmental legislation.

In line with this argument, Fombrum and Shanley (1990) suggest that favorable reputations can generate excess returns by permitting firms to charge premium prices, hire the best people, and attract investors. Moreover, a good reputation helps firms in negotiations with stakeholders. In fact, a good social reputation is a positive signal of a firm's ability to honor claims in the future. In so doing, building upon a firm's activities in a social context is a way to start a positive spiral of reactions with stakeholders that are directly or indirectly involved in the company.

As employers, firms with better reputations are typically leaders in attracting excellence, even if they offer lower salaries than competitors. For potential employees, career opportunities and firm's stability in the external environment can offset lower compensation.

From a profitability standpoint, CS entails cost, but those costs can be rationalized by the resulting benefits, which might include lower costs in other areas or higher revenues (Perrini \& Russo, 2008; Perrini et al., 2011). Lower costs can result, for instance, from a reduction in the expected volatility of cash flows. In contrast, being socially or environmentally irresponsible might create problems for a firm in the medium to long term. For example, if we estimate the effect of expected losses from bad management on the capacity to repay debt, the result is a considerable decrease in company value. On the other hand, a company that is socially and environmentally responsible will have fewer problems of this kind, as it should show a better ability to repay debt over the time. In terms of opportunities, financing costs for these two firms will differ notably. Finally, we can conclude that lower rates applied by financing institutions represent cost savings for responsible firms.

For the above reasons, companies are continually trying to determine how they can best build a reputation for sustainability (Fombrum \& Shanley, 1990). Along this line, researchers and practitioners would most likely agree that firms are increasingly interested in signaling that they are engaged in credible socially and environmentally responsible behaviors. In turn, the benefits of a good reputation have contributed to the development of a new business sector that reviews the sustainability activities of companies and issues relevant reports (Fowler \& Hope, 2007).

\subsection{Socially Responsible Investing and Firm Value}

Within this context, inclusion in sustainability indexes and socially responsible investing (SRI) portfolios can be one way for a firm to signal commitment to sustainability. Sustainability indexes are important because they are an external body that serves as an information intermediary between a firm and its stakeholders. Sustainability indexes make objective, neutral, professional assessments of each company's sustainability reports (Dubbink, Graafland, \& van Liedekerke, 2008).

In the past, SRI funds decided where to invest on the basis of analyses made by private CS agencies. In fact, in order to effectively administer their SRI portfolios, investment managers are likely to buy this service from external parties to obtain a more objective assessment of firms' sustainability. For example, the Kinder Linder Domini (KLD) database assesses the sustainability profile of 3,000 US-based companies. More recently, numerous indexes have taken the scene, ranking and listing companies according to social and environmental parameters for investments. For example, Dow Jones and the Financial Times and London Stock Exchange (FTSE) have both launched indexes aimed at evaluating the most important corporations according to their social, environmental, and economic profiles. These companies work to fill the gap between fund managers, who wanted to grow their SRI target stocks, and companies that are becoming increasingly interested in highlighting their commitment to social responsibility and, thereby, increasing their reputation.

Notably, in order to create a reliable benchmark and provide valuable comparisons, the processes of selecting new components and monitoring existing components follow specific metrics and deadlines. In this regard, the Italian experience with ECPI is worthy of mention. The ECPI group was the pioneer in the creations of sustainability 
indexes and benchmarks in Italy. Since its establishment in 1997, the group has offered a wide range of solutions in terms of research, rating, and sector exclusions according to three main parameters: environmental, social, and governance (ESG) criteria (ECPIgroup.com, 2011).

In general, CS activities help firms build reputational capital, thereby improving their ability to negotiate more attractive contracts with suppliers and governments. CS activities also enable them to charge premium prices for their products and reduce their cost of capital as well as other costs (Robinson, Kleffner \& Bertels, 2011).

However, thus far, little research has attempted to address whether inclusion in sustainability indexes has a significant impact on firm value for listed and unlisted corporations (Fowler \& Hope, 2007). One notable exception is Curran and Moran (2007), who analyze the impact of listing and delisting for companies included in FTSE4Good index. Their findings provide limited evidence of a connection between the firm's share price and a listing or delisting.

Another significant study about the connection between firm's value and CS is found in Consolandi et al. (2008), who conduct a detailed and statistically important analysis of the impact of inclusion in the Dow Jones Sustainability Index (DJSI) on stock prices. The first objective of their analysis is to compare the DJSI with a Surrogate Complementary Index (SCI) that includes all of the stocks listed in DJ Stoxx (official benchmark for DJSI) except for the stocks that are part of the DJSI. Not surprisingly, the comparison shows higher returns for the DJSI and a lower standard deviation (i.e., less risky investment). The second objective of the analysis is to explore the direct impact of a listing in the DJSI with respect to included/excluded firms' share prices. The authors use the CAAR of a company's stock to test whether signaling CS through acquiring/losing a listing in the DJSI results in positive/negative reactions in the market. The findings statistically confirm the signs of the reactions, which are positive for additions and negative for deletions. However, the negative impact of a delisting appeared to be greater than the positive effect for two reasons. First, given the large capitalization of companies in DJSI, the impact of listing is negligible, as these companies' reputations are already know in the market. Second, a delisting indicates a considerable deterioration in a company's sustainable performance, which catches the market's attention. This is immediately reflected in a decrease in the share price (Consolandi et al., 2008).

\subsection{Hypotheses}

In light of the above theoretical context, one aim of this study is to test the effect of being delisted from sustainability indexes on firm performance. In testing our hypotheses, we consider both the long-term effect on a firm's market value and the short-term stock market reaction. The first set of hypotheses follows:

Hypothesis 1: A delisting from a sustainability index negatively influences a firm's market value

Hypothesis 2: The stock price of a firm that was delisted from a sustainability index falls: (2a) in the ten trading days before the announcement of delisting; (2b) following the delisting announcement; and (2c) in the ten trading days following the effective date of the delisting.

A strategic perspective should also be considered in order to develop a clearer picture of the mechanisms surrounding delisting's effect on firm performance. In other words, the strategic criteria typically used to assess the sustainability orientation of the firms included in a sustainability index must be considered. Therefore, our second set of hypotheses focuses on the effect of specific sustainability criteria on the performance of those firms that are delisted from a sustainability index. More specifically, we propose the following:

Hypothesis 3: A delisting from a sustainability index owing to a failure to meet sustainability criteria negatively affects the firm's: (3a) market value and (3b) performance on the stock market.

Lastly, given the global nature of SRI and the impact that different stock markets can have on firm value and stock profitability, we test the moderating effect of the stock market on the negative relationship between removal from a sustainability index and both the firm's market value and its stock returns. Our final set of hypotheses is as follows:

Hypothesis 4: A listing on a country-specific stock exchange positively moderates the negative relationship between being delisted from a sustainability index and the firm's: (4a) market value, (4b) performance on the stock market in the ten trading days before the delisting announcement, $(4 \mathrm{c})$ performance on the stock market following the delisting announcement, and (4d) performance on the stock market in the ten trading days following the effective date of the delisting. 


\section{Methodology}

\subsection{Sample and Analysis}

This study investigates whether removal from a sustainability index affects a firm's market value and corporate performance using a sample of firms that were included and removed from the FTSE4Good Global Index. Given that the criteria for inclusion/deletion became more homogenous and accessible after 2008, the analysis focuses on the period from 2008 to 2011 . The entire population of companies that were initially listed in the index and then delisted during the period of observation were included in the analysis. After removing observations with missing data, 151 firms were left in our sample, which we used to test our hypotheses through a panel data analysis.

Panel data have to be treated carefully because the set of observations is likely to be inter-correlated. To check for firm-specific heterogeneity, which is impossible to measure but has a significant impact on firm value, we utilized a longitudinal model (Shin-Fang \& Her-Jiun, 2007).

Notably, the use of unbalanced panel data allows the number of periods for each firm to differ. Furthermore, we have panel data for $t$ years for $i$ firms. Our model can be represented by the following equation:

$$
y_{i t}=\alpha_{i}+\beta^{\prime}{ }_{0} D_{i t}+\beta^{\prime}{ }_{1} C_{i t}+\varepsilon_{i t}
$$

in which $\alpha_{i}$ is a constant representing the effects of omitted variables that are specific to the $i$ th firm (Hsiao, 1991). $y_{i t}$ symbolizes the firm's value, $D_{i t}$ is a dummy variable that equals 1 if a firm has been delisted from the sustainability index and 0 otherwise, and $C_{i t}$ refers to the control variables that have been used in the past for this type of analysis (i.e., firm size, financial leverage, profitability, and industry effect). $\beta_{0}^{\prime}$ and $\beta_{1}^{\prime}$ are the panel-regression coefficients, while $\varepsilon_{i t}$ is the error term that is assumed to be an independent and identically distributed variable with a mean of zero and constant variance of $\sigma^{2}$. As the variance of the composite error term, $\alpha_{i}+$ $\varepsilon_{i t}$, is unknown, a feasible generalized least square (FGLS) model was used (Lo \& Sheu, 2007).

The problem of endogeneity was addressed when building the dataset. In fact, the dependent variables were calculated using the information applicable at the end of the year following the event, while the independent variables' values were assigned prior to the end of the year. Given that the FTSE Committee makes decisions regarding the sustainability of the firms included in the index twice a year and then announces the decision (in March and September), we computed the dependent variable one year after a delisting. This ensured that our "cause" (a delisting or a lack thereof) precedes the "consequence" (i.e., the firm's market value and stock-market performance). Moreover, in order to minimize the potential effect of simultaneity bias arising from contemporaneous cross-sectional analysis, all independent variables were lagged by one period, as is common in longitudinal studies (Greene, 2003).

Furthermore, different sets of hypotheses were used. In the first step, the correlation between delisting from a sustainability index and a firm's performance was tested. Second, a more in depth analysis was undertaken in order to understand the effects of each of the criteria that led to the company's delisting on the dependent variables. Third, the moderation effect arising from firms' listings on specific stock exchanges was observed.

\subsection{The Dependent Variables}

Market value. To test the effect of a delisting from a sustainability index on a firm's market value, we used Tobin's Q. In this study, Tobin's Q was computed as the ratio of the market value of a firm to the replacement cost of the firm's assets. The $\mathrm{Q}$ ratio is useful for determining the valuation of a company, and it is based on the hypothesis that the market value of a company should, over the long run, roughly equal the cost of replacing the company's assets. If the value of this ratio is greater than 1 , any investment made by the firm has the potential to generate value. If the value of this ratio is between 0 and 1 , firms should avoid making investments because any action will destroy value for stakeholders. Moreover, it is generally accepted that Tobin's Q offers a better comparison across firms than other accounting measures (Lang \& Stulz, 1997).

Stock-market performance. The second dependent variable against which the theoretical framework is tested is the Cumulative Average Abnormal Return (CAAR) of the firm. In the short term, "performances" refers to the stock-price disadvantage arising from the inclusion in or deletion from FTSE4Good. This analysis is clearly limited to the short run, and it clarifies the signaling effects of delisting announcements.

The FTSE4Good Committee selects leading companies in sustainability from the FTSE All-World Index during two semi-annual methodology reviews. The resulting changes to the index composition are announced in March and September. After a minimum of two weeks, these changes are implemented on the third Friday of March and September after the official closing prices have been determined. In order to take the announcement's effect on 
stock-market performance and on stock trading volumes must, both refer to the announcement date (AD) and to the date on which the index is effectively changed (ED).

In line with previous research (Consolandi et al., 2008), the event window for the calculation of CAAR was divided into the following sub-periods: (1) pre-announcement (AD-10:AD-1), which controls for whether there was any expectation of the Committee's decision or leakage of information; (2) post-announcement (AD:ED), which verifies the market's reaction at the time of the disclosure; (3) post-effective (ED+1:ED+10), which indicates whether there was any lagged impact or slow assimilation of information. This methodology computes the abnormal returns for each added/deleted stock as the return on the stock minus the return of the benchmark FTSE All-World Index during every day in the period considered in the analysis. Finally, the mean of these abnormal returns in each of the event periods was used in order to ensure a symmetric distribution of the values.

\subsection{The Predictors}

Index deletion. In this study, commitment to CS was computed using the index deletion variable, which assumed a value of 1 if the company had been delisted from the sustainability index in a given period, and 0 otherwise. The first set of hypotheses tests how the market reacts to this information, and whether there is a negative impact on firm value measured in terms of Tobin's Q or on the share price consequent to the announcement of the delisting. An understanding of how the market prices this information is important for helping firms understand the importance of a presence in this area.

Sustainability criteria. A company that is listed in the FTSE4Good index must maintain a specific commitment to each of the criteria set by the Committee. If a member does not respect one or more of these criteria, the result is the deletion of the firm from the index in the next review session. In order to track the market's response to the firm's different sustainable scores, a dummy variable was created for each of the five criteria used by the FTSE4Good: (1) working towards environmental sustainability, (2) upholding and supporting universal human rights, (3) ensuring good labor standards in the supply chain, (4) countering bribery, and (5) mitigating and adapting to climate change. Each of these dummy variables assumed a value of 1 if the criterion had not been respected, and 0 otherwise.

Moderating effect: country-specific stock exchange. To test the moderating effect of being listed on a particular stock exchange, three dummy variables were used for the stock exchanges on which sample firms were listed: Asia, Europe, and North America. The dummy variables were coded 1 if the firm was listed on a particular country-specific stock exchange, and 0 otherwise. Europe was used as the base value. Moreover, the product of the dummy variable and index deletion was computed in order to measure the moderating effect.

\subsection{Control Variables}

In order to state that sustainability enhances the value of firms, it is necessary to control for the effect of other variables that could affect company value (Lo \& Sheu, 2007). Several control variables were therefore included in the regression models.

The majority of previous literature finds that size is correlated with firm value (McConnell \& Servaes, 1990; Smith $\&$ Watts, 1992). We therefore controlled for firm size using the logarithm of total number of employees at time $t$. The extant literature has also demonstrated how the capital structure of a company can influence a firm's value (Palia, 2001). To control for the capital-structure effect, we used a leverage variable, which was computed as the debt to equity ratio (total liabilities to total equity). If one firm is more profitable than another, it is more likely to be traded at a premium in the stock market. As this could impact our independent variables, we controlled for profitability using return on assets (ROA), which is one of the strongest measures of profitability. ROA was calculated as net income (loss) on the firm's total assets of the firm.

Given the global economic situation, firm value might be influenced by the period of observation. Therefore, we controlled for the period of observation using four period-effect dummies: 2008, 2009, 2010, and 2011. We assigned each of the dummies a value of 1 if an event occurred in a specific year, and 0 otherwise. Moreover, firms included in the FTSE4Good index are classified by sector. We therefore controlled for industry effects using the following economic sector dummies: energy products and services; industrial manufacturers; media and communication; pharmaceutical and health care equipment; software and computer services; travel and leisure and retail services; and banks, financial services and real estate.

Finally, firms distributing dividends to shareholders are typically viewed as firms that do not need to re-invest that money in projects that could generate a positive net present value because they already have good portfolios. Firms that have paid a dividend are less likely to be capital constrained, which may result in lower firm performance (Lang 
\& Stulz, 1994). To control for investors' return, we calculated earnings per share (EPS) as the natural logarithm of the variable (to reduce variance).

\section{Results}

The results of the regressions performed in this study are summarized in the following tables. A hierarchical procedure was used in the regression models, such that the effect of the control variables was considered first, after which the predictors were included. To make it easier to read the tables and results, the period and industry effects are not presented in the tables.

Table 1. Results of hypotheses tests: the effect of delisting on performance and the moderating effect

\begin{tabular}{|c|c|c|c|c|c|c|}
\hline Variable & $\begin{array}{c}\text { Model 1: } \\
\text { Control } \\
\text { variables }\end{array}$ & $\begin{array}{l}\text { Model 2: } \\
\text { Tobin's Q }\end{array}$ & $\begin{array}{c}\text { Model 3: } \\
\text { CAAR } \\
\text { pre-announc. }\end{array}$ & $\begin{array}{c}\text { Model 4: } \\
\text { CAAR } \\
\text { post-announc. }\end{array}$ & $\begin{array}{c}\text { Model 5: } \\
\text { CAAR } \\
\text { post-effective } \\
\text { date }\end{array}$ & $\begin{array}{c}\text { Model 6: } \\
\text { CAAR } \\
\text { post-announc. } \\
\text { and mod. effect }\end{array}$ \\
\hline Intercept & 3.50 & $3.20 * * *$ & -0.20 & 0.96 & 1.02 & $1.71^{*}$ \\
\hline Industry effect & Yes & Yes & Yes & Yes & Yes & Yes \\
\hline Period effect & Yes & Yes & Yes & Yes & Yes & Yes \\
\hline Profitability & $4.60 * * *$ & $4.82 * * *$ & -0.46 & $-1.70^{*}$ & 1.41 & -1.15 \\
\hline Size & 0.84 & 1.60 & 1.10 & 0.30 & -0.95 & 0.74 \\
\hline Leverage & -1.25 & -1.23 & -0.09 & 1.35 & -0.16 & $1.86^{*}$ \\
\hline EPS & -1.36 & -0.66 & -0.25 & 0.90 & -0.56 & 1.57 \\
\hline Deletion & & $-2.03 * *$ & $1.94 * *$ & $-8.57 * * *$ & 0.40 & $-6.90 * * *$ \\
\hline Asia \& Oceania & & & & & & $-2.19 * * *$ \\
\hline Europe & & & & & & $-1.77^{*}$ \\
\hline North America & & & & & & $-3.23 * * *$ \\
\hline Deletion x Asia & & & & & & $2.71^{* * *}$ \\
\hline $\begin{array}{l}\text { Deletion x North } \\
\text { America }\end{array}$ & & & & & & $2.84^{* * *}$ \\
\hline $\mathrm{R}^{2}$ & 0.376 & 0.405 & 0.227 & 0.441 & 0.114 & 0.476 \\
\hline Adjusted $\mathrm{R}^{2}$ & 0.324 & 0.339 & 0.152 & 0.367 & 0.041 & 0.427 \\
\hline $\mathrm{F}$ & 9.35 & 9.02 & 2.85 & 7.67 & 1.25 & 7.30 \\
\hline $\mathrm{p}<$ & 0.000 & 0.000 & 0.000 & 0.000 & 0.247 & 0.000 \\
\hline
\end{tabular}

Table 1 presents the results related to the first set of hypotheses. In particular, Model 2 challenges whether being delisted from the sustainability index affects the firm's value when measured using Tobin's Q. Our results provide evidence of a statistically significant $(\mathrm{p}<0.05)$ and negative $(r=-2.03)$ relationship. Therefore, Hypothesis 1 is supported. Model 3 presents the analysis of the impact of a delisting on stock-market returns in the ten trading days preceding the disclosure of FTSE4Good's judgment. The results indicate that prior to the announcement, the stocks of the companies affected experience positive $(r=1.94)$ and statistically significant $(\mathrm{p}<0.05)$ returns. Therefore, Hypothesis 2a is not supported.

Model 4 looks at stock returns over all trading days for the stocks in the sample from the day of the announcement until the date on which the changes are effectively implemented. In this case, the coefficient of the deletion variable is negative $(\mathrm{r}=-8.57)$ and statistically significant $(\mathrm{p}<0.01)$. This confirms a negative relationship between delisting from a sustainability index and stock-market returns after the announcement, which supports Hypothesis $2 \mathrm{~b}$.

Finally, the results of our test of Hypothesis 2c are presented in Model 5. This model investigates the relationship between a delisting decision and the stock-market reaction in the ten days after the effective day of the change. In this case, the model's overall significance is negligible.

The second set of hypotheses addresses how the market reacts when a company fails to meet the sustainability criteria. The results of these regressions are summarized in Table 2. 
Table 2. Results of hypotheses tests: Effects of sustainability criteria on performance

\begin{tabular}{lcccc}
\hline Variable & $\begin{array}{c}\text { Model 7: } \\
\text { Tobin's Q }\end{array}$ & $\begin{array}{c}\text { Model 8: } \\
\text { CAAR } \\
\text { pre-announc. }\end{array}$ & $\begin{array}{c}\text { Model 9: } \\
\text { CAAR } \\
\text { post-announc. }\end{array}$ & $\begin{array}{c}\text { Model 10: } \\
\text { CAAR post-effective date }\end{array}$ \\
\hline Intercept & $3.39^{* * *}$ & -0.01 & 1.47 & 0.97 \\
Industry effect & Yes & Yes & Yes & Yes \\
Period effect & Yes & Yes & Yes & Yes \\
Profitability & $4.44^{* * *}$ & 0.61 & $-1-56$ & 1.50 \\
Size & 1.18 & 0.37 & 0.15 & -0.86 \\
Leverage & $-1-32$ & -0.01 & 1.35 & 0.03 \\
EPS & 0.93 & 0.89 & 0.45 & -0.71 \\
Environmental & 0.07 & -0.17 & $-3.59^{* * *}$ & -0.59 \\
Human and labor rights & -0.99 & $4.20^{* * *}$ & $-4.05^{* * *}$ & 0.22 \\
Good supply chain standard & -0.12 & 0.01 & -0.75 & -0.42 \\
Countering bribery & $-1.79^{*}$ & $-1-43$ & $-3.98^{* * *}$ & 0.98 \\
Adapting to climate change & -0.05 & 0.67 & $-2.75^{* * *}$ & 1.33 \\
$\mathrm{R}^{2}$ & 0.411 & 0.30 & 0.406 & 0.135 \\
Adjusted $\mathrm{R}^{2}$ & 0.336 & 0.213 & 0.304 & 0.040 \\
F & 5.94 & 3.10 & 5.01 & 1.15 \\
$\mathrm{p}<$ & 0.000 & 0.000 & 0.000 & 0.313
\end{tabular}

Note: $* * * \mathrm{p}<0.01 ; * * \mathrm{p}<0.05 ; * \mathrm{p}<0.10$

The results for Model 7 reveal the impact of each sustainability criteria on the firm's market value. In terms of the statistical significance of the coefficients, the only criterion for which a statistical relationship is evident is countering bribery. This coefficient is statistically significant $(\mathrm{p}<0.05)$ and negative $(\mathrm{r}=-1.79)$, which highlights the negative relationship between a firm's value and a delisting based on the firm's failure to counter bribery. Therefore, Hypothesis $3 \mathrm{a}$ is supported for this criterion. The coefficient is not significant for the environmental criterion in Model 7. Therefore, environmental issues have no direct negative impact on value (when measured using Tobin's Q) for the firms in our sample. The same conclusion can be drawn for the supply chain labor standards, the respecting human labor conditions, and the climate change criteria.

The results differ for the impact of each criterion on stock returns. Model 8 shows the results of hypotheses tests related to the trading days prior to the revelation of the Committee's decision. In terms of the sustainability criteria coefficients, there is no empirical evidence that enables us to determine the kind of the relationship between CAAR and the following criteria: an environmental focus, good supply chain labor standards, adapting to climate change, and countering bribery. As the respective $t$ statistics and $p$ values are not significant, the evidence does not support our hypothesis. Different implications appear for the human and labor rights criterion. In fact, the coefficient has a positive sign $(r=4.20)$ and it is strongly statistically significant $(\mathrm{p}<0.01)$. This is exactly the opposite of our hypothesis, which is therefore not supported.

The results for Model 9 show the reaction of the stock market measured in terms of the relationship between CAAR and the reason for delisting (sustainability criteria) in the post-announcement period, which includes all of the trading days for the stocks in our sample from the day of the announcement to the date when the changes are effectively implemented. The results provide empirical evidence of a strong statistical relationship. In fact, almost all of the coefficients for each of the sustainability criteria are significant. With the exception of good supply chain standards, the criteria (i.e., environmental, human and labor rights, countering bribery, and adapting to climate change) are strongly statistically significant $(\mathrm{p}<0.01)$ and negative $(\mathrm{r}=-3.59,-4.05,-3.98$, and -2.75 , respectively). The signs and significance of these explanatory variables offer statistical support for a negative relationship between CAAR post-announcement performance and delisting resulting from a failure to meet the minimum requirements in the related fields. Therefore, Hypothesis $3 \mathrm{~b}$ is mostly supported. 
Model 10 presents the results related to the CAAR for the 10 days following the effective implementation of changes. Overall, we cannot conclude that there is a relationship during the time of observation given the non-significance of the model.

As the sample was populated with firms listed on different stock exchanges, we also analyzed whether a listing on one of the three main stock exchanges (Asia, Europe, and North America) moderates the negative effect of being delisted from the sustainability index. The results of this analysis are showed in Table 1. This analysis was undertaken for of the all different event windows. However, we report only the most significant outputs, which are related to CAAR in the post-announcement period.

As shown in Model 6, investors' responses differ according to where the firm is listed. With regard to stock returns, the stock exchange on which a company is listed has a moderating effect. The coefficients for the moderating effects driven by a listing on the Asian and North American stock exchanges are strongly statistically significant $(\mathrm{p}<0.01)$ and positive ( $\mathrm{r}=2.71$ and $\mathrm{r}=2.84$, respectively). Therefore, Hypothesis $4 \mathrm{~b}$ is strongly supported.

\section{Discussion}

The results presented in this study suggest that the market is responsive to corporate investments in sustainability and that being excluded from a sustainability index generates a signaling mechanism that leads to a reduction in value for the affected company. Moreover, the relation between delisting and stock returns in the days immediately prior to and in the period after the announcement is interesting. These general results have implications for both researchers and practitioners interested in SRI.

Our first set of hypotheses investigates the relationship between firm performance and deletion from a sustainability index. We argue that the market views delisting as an opportunity for the firm to release some resources that can be employed differently in the short run. If firms view maintaining membership in the FTSE4Good index as an investment, the response of the market is in line with the typical response to a company decision to re-allocate resources. Nevertheless, it is important to note that these results are associated with rumors on the stock exchange and related to the possibility that information has been leaked.

On the other hand, the negative relationship between CAAR and being delisted from the sustainability index points to a market reaction soon after the disclosure of survey results. In fact, the market reacts in this way because it relies on the Committee's activities. Given the uncertainty in the market, it is becoming increasingly important for external parties to monitor the commitment of a firm to CS and to publish related scores by pre-determined deadlines. If these scores do not match expectations, the immediate result is a detrimental effect on company performance.

Finally, our results suggest that information does not have a lagged impact on the market and that it is not slowly assimilated. We can therefore conclude that the consequences are absorbed at the time of the first disclosure of the Committee's decision. Another important piece of this puzzle is that the Committee has never reversed its judgment, i.e., it has never allowed an excluded company to be relisted. This suggests that the overall monitoring process is highly accurate.

Our second set of hypotheses refers to the relevance of specific sustainability criteria in explaining the effect of a delisting on firm performance. Given the significance of the coefficients, the criterion that has the greatest effect on the negative relationship between a firm's value and a delisting is countering bribery. Bribery is generally defined as an offer or receipt of any gift, loan, fee, reward or other advantage to or from any person as an inducement to do something which is dishonest, illegal or a breach of trust in the conduct of the enterprise's business. Investors pay close attention to this aspect of business and, as demonstrated by the negative relationship found in this study, a lack of transparency in this regard is reflected in a reduction in the firm's value. However, there is no statistical support affirming a similar relationship between a firm's market value and being delisted for not having respected the other criteria.

The results obtained in our analysis of the relationship between CAAR and sustainability specific criteria are also notable. The first round of regressions performed on the CAARs computed for the pre-announcement period highlights an interesting positive relationship between the human and labor rights criterion and CAAR. One possible managerial implication of this result is that investors initially view a decision to delist a company as an indicator of lower costs. Some consideration is needed in order to clarify why this criterion is correlated with a positive reaction. The companies that are selected for inclusion on FTSE4Good are the largest firms on the stock exchange in terms of market capitalization and number of employees. For these reasons, a reduction in the resources that a firm dedicates to CS activities is significant. In the short run, the company can take advantage of this reduction by using the money for other business activities. 
However, this short-term reaction is overturned when the FTSE Committee communicates the firm's score. The results suggest a negative relationship between CAAR and a lack of commitment to each of the areas observed by the Committee in the post-announcement period. The decline in stock returns following the announcement suggests, once again, that a firm must balance its ethical side with its economic side. In fact, a company that poorly manages environmental aspects, fails to meet human and labor rights standards, shows little propensity to adapt to climate change challenges, and fails to counter bribery is clearly penalized by investors.

Notably, this relationship does not apply to a firm's commitment to labor standards in the supply chain. In fact, the lack of significance for this criterion's coefficient indicates that investors do not penalize companies for aspects of their businesses that are not under their direct control. This may be because large organizations have networks that include so many actors that it is difficult for them to recognize the CS efforts of those companies.

We also considered the effect of a delisting in the ten trading days after the effective implementation of the changes. The model's lack of significance confirms that information is not slowly assimilated and there is no lagged impact on stock returns.

Finally, the results provide information regarding whether the stock exchange on which a firm is listed has an impact on the effect of a delisting from the index. The results show that companies listed in North America and Asia are less affected than those listed in Europe. In fact, the negative relationship between CAAR and delisting differs in the Asian and North American markets, compared to European stock markets.

\section{Conclusions}

Many researchers (e.g., Robinson et al., 2011; Shin-Fang Lo et al., 2007) provide empirical evidence suggesting that firms and investors view a listing on a sustainability index as an important method of establishing a reputation for sustainability. This paper aimed to analyze the opposite side of the coin by investigating how a delisting from such an index affects a firm's value and stock returns.

Our results suggest that the market punishes firms for not integrating environmental and social concerns when developing strategies. If we view Tobin's Q as proxy for firm's value, we find that a firm's value is closely associated with CS, such that being delisted from a sustainability index has a negative impact on value.

Moreover, we analyzed the market's response in the form of stock returns in the days preceding the announcement, in the post-announcement period, and following the implementation of changes. The results are surprising. In fact, in the pre-announcement period (ten trading days before the disclosure of the survey results), we find a positive, statistically significant relationship between a delisting and the stock-market reaction. Therefore, we argue that because maintaining the membership in a sustainability index is costly for firms, a delisting frees up resources that can be allocated to other projects. However, as the actual scores are not disclosed in the pre-announcement period, these changes reflect information leakages or rumors in the market. In contrast, a negative relationship exists between a delisting and stock-market reactions when the Committee's decision is made public (the post-announcement period). Finally, we show that there is no lagged impact or slow assimilation of information in the ten trading days after the effective date of the index changes.

The second set of hypotheses aimed at improving our understanding of the main drivers of these relationships. In this regard, five sustainability criteria were considered. We found that those firms experienced a greater negative impact on value were those with a negative score on the countering bribery criterion. The managerial implication of this result is that investors focus on how a company interacts with external stakeholders and, more specifically, whether bribery is used. Bribery is viewed as a practice undermines the future sustainability and profitability of a corporation. At the same time, we find a positive relationship in the pre-announcement period, which is mainly driven by the divestment in the human and labor rights standards. This is undoubtedly the most expensive area in which a company must invest in order to maintain its listing on a sustainability index, which is why the market considers how these resources can be allocated following a divestment. In addition, in the post-announcement period, four of the five criteria have a negative, statistically significant coefficient. Only the supply chain labor standards criterion appears to be unimportant from an investor's standpoint. The reason for this may be related to the fact that firms in our sample are large, such that they have numerous partners that have their own sustainability scores, which the focal firm cannot directly control.

In conclusion, as the companies in our sample were spread around the world and listed on different stock exchanges, we examined the moderation effect of the stock exchange on which each firm was listed. The results showed that investors in different areas show differing sensitivities to sustainability topics. Country-specific effects are therefore evident with regard to a delisting from a sustainability index. 


\subsection{Limits and Cues for Future Research}

This study highlights several possibilities for additional investigations into the nature and structure of socially responsible investments, with special emphasis on the relation between the inclusion and deletion from a sustainability index and firm market value and performance. The availability of a generalized framework for measuring the quality of a good socially responsible investment could be useful in this regard.

Researchers might wish to investigate the moderating effects influencing the relationship between the SRI decisions and different other variables not included in this study. Example of these variables could be the selection criteria used to actively select the portfolio composition as well as the characteristics of the portfolio such as size and diversification degree. Such research would contribute to a better understanding of the determinants of the performance of SRI, whereas a lack of knowledge still exists on the factors affecting the well-known and investigated higher performance of SRI compared to the so called traditional investing decisions.

This study has limits of course, which future researches could overcome. In this regard, the use of other samples or of indicators of performance other than Tobin's Q and CAAR may represent interesting extensions of this research path. As an example, the use of operating performances could generate additional insights based on a different perspective of the quality of SRI.

Moreover, considering a longer period of analysis can improve the significance of our results, shifting the attention not only on the short-period performance, but also on the medium and long-term perspective. This alternative perspective could provide additional strategic implications that could be of interest for researchers and practitioners interested in SRI.

\section{Acknowledgements}

We thank the Editor of the International Journal of Business Administration and the anonymous reviewers for their comments and support. We also thank Francesco Rizzitelli for his support in collecting data and developing a first draft of this article. The authors contributed equally to this work.

\section{References}

Bertel, S., \& Peloza, J. (2008). Running Just to Stand Still? Managing CSR Reputation in an era of Ratcheting expectation. Corporate Reputation Review, 56-72. http://dx.doi.org/10.1057/crr.2008.1

Conner, S. L. (2009). Sustainability Stock Indices: Are Companies Missing Marketing Opportunities? Society for Marketing Advances Proceedings.

Consolandi, C., Jaiswal-Dale, A., Poggiani, E., \& Vercelli, A. (2008). Global Standards and Ethical Stock Indexes: The Case of the Dow Jones Sustainability Stoxx Index. Journal of Business Ethics, 87, 185-197. http://dx.doi.org/10.1007/s10551-008-9793-1

Curran, B., \& Moran, D. (2007). Impact of FTSE4Good on Firm Price: An Event Study. Journal of Environmental Management, 529-537. http://dx.doi.org/10.1016/j.jenvman.2006.02.010

Doh, J. P., S. D. Howton, S. W., Howton, \& Siegel, D. (2010). Does the Market Respond to an Endorsement of Social Responsibility? The Role of Institutions, Information and Legitimacy. Journal of Management, 36, 1461-1485. http://dx.doi.org/10.1177/0149206309337896

Dubbink, W., Graafland, J., \& van Liedekerke, L. (2008). CSR transparency and the Role of Intermediate Organization. Journal of Business Ethics, 391-406. http://dx.doi.org/10.1007/s10551-008-9893-y

Elkington, J. (2004). The triple bottom line, does it all add up?: assessing the sustainability of business and CSR. Earthscan.

Fisher, D. (2010). Leading a sustainable organization. Journal for Quality \& Participation, 29-31.

Fombrum, C., \& Shanley, M. (1990). What's in a name? Reputation Building and Corporate Strategy. Academy of Management Journal, 233-258. http://dx.doi.org/10.2307/256324

Fowler, S., \& Hope, C. (2007). A critical review of Sustainable business indices and Their impact. Journal of Business Ethics, 243-252. http://dx.doi.org/10.1007/s10551-007-9590-2

Greene, W. (2003). Econometric Analysis. New York: Prentice Hall.

Hsiao, B. (1991). Analysis of Panel Data. Cambridge: Cambridge University Press.

Lang, L., \& Stulz, R. (1994). Tobin's Q Corporate Diversification and Firm performance. Journal of Political Economy, 1248-1280. http://dx.doi.org/10.1086/261970 
Lo, S.-F., \& Sheu, H.-J. (2007). Is Corporate Sustainability a Value-Increasing Strategy for Business? Corporate Governance: An International Review, 345-358.

McConnell, J., \& Servaes, H. (1990). Additional evidence on Equity Ownership and Corporate Value. Journal of Financial Economics, 595-612. http://dx.doi.org/10.1016/0304-405X(90)90069-C

McDonough, William, \& Braungart, M. (2002). Cradle to cradle: remaking the way we make things (1st ed.). New York: North Point Press.

Montiel, I. (2008). Corporate Social Responsibility and Corporate Sustainability: Separate Pasts, Common Future. Organization \& Environment, 245-269. http://dx.doi.org/10.1177/1086026608321329

Nygaard, S., \& A. Russo (2008). Trust, Coordination and Knowledge Flows in R\&D Projects: The Case of Fuel Cell Technologies. Business Ethics: A European Review, 17(1), 24-34.

Orlitzky, M., \& Benjamin, J. (2001). Corporate Social Performance and Firm Risk: A Meta-analytic Review. Business\&Society, 369-396. http://dx.doi.org/10.1177/000765030104000402

Palia, D. (2001). The Endogeneity of Managerial Compensation in Firm Value. The Review of financial studies, 735-764. http://dx.doi.org/10.1093/rfs/14.3.735

Panapanaan, V., Linnanen, M., Karvonen, M., \& Phan, V.T., (2003). Roadmapping CSR in Finnish Companies. Journal of Business Ethics, 133-148. http://dx.doi.org/10.1023/A:1023391530903

Perrini, F., \& A. Russo (2008). illycaffè: Value Creation through Responsible Supplier Relationships. Journal of Business Ethics Education, 5(Special Issue), 83-114.

Perrini, F., Russo, A., Tencati, A., \& Vurro, C. (2011). Deconstructing the Rrelationship between Corporate Social and Financial Performance. Journal of Business Ethics, 102(Supp.1), 59-76. http://dx.doi.org/10.1007/s10551-011-1194-1

Pogutz, S., Russo, A., \& P. Migliavacca (eds.). (2009). Innovation, Markets and Sustainable Energy: The Challenge of Hydrogen and Fuel Cells (Edward Elgar, Cheltenham Glos, UK). http://dx.doi.org/10.4337/9781848449329

Rindova, V., Williamamson, A., Petkova, P., \& Server, M. (2005). Being good or being known: An empirical examination of the dimensions, antecedents, and Consequences of Organizational Reputation. Academy of Management Journal, 1033-1093. http://dx.doi.org/10.5465/AMJ.2005.19573108

Roberts, P., \& Dowling, G. (2002). Corporate Reputation and Sustained Superior Financial Performance: A survey of the Literature. Corporate Reputation Review, 1077-1093.

Robinson, M., Kleffner, A., \& Bertels, S. (2011). Signaling Sustainability Leadership: Empirical Evidence of the value of DJSI Membership. Journal of business Ethics, 493-505. http://dx.doi.org/10.1007/s10551-011-0735-y

Russell Sparkes, R., \& Cowton, C. J. (2004). The Maturing of Socially Responsible Investment: A Review of the Developing Link with Corporate Social Responsibility. Journal of Business Ethics, 52(1), 45-57. http://dx.doi.org/10.1023/B:BUSI.0000033106.43260.99

Russo, A., \& Tencati, A. (2009). Formal vs Informal CSR Strategies. Evidence from Italian Micro, Small, Medium-sized, and Large Firms. Journal of Business Ethics, 85(Supp.2), 339-353. http://dx.doi.org/10.1007/s10551-008-9736-x

Schueth, S. (2003). Socially Responsible Investing in the United States. Journal of Business Ethics, 43(3), 189-194. http://dx.doi.org/10.1023/A:1022981828869

Sen, S., \& Bhattacharya. (2001). Does doing good always lead to doing better? Consumer reactions to Corporate Social Responsibility. Corporate Reputation Review, 225-243.

Shin-Fang, L., \& Her-Jiun, S. (2007). Is corporate sustainability a Value-Increasing Strategy for Business? Corporate Governance: An International Review, 345-358.

Smith, C., \& Watts, R. (1992). The investment Opportunity Set and Corporate Financing, Dividend and Compensation Policies. Journal of Financial Economics, 263-292. http://dx.doi.org/10.1016/0304-405X(92)90029-W

van Marrewijk, M. (2003). Concepts and Definitions of CSR and Corporate Sustainability: Between Agency and Communion. Journal of Business Ethics, 95-105. http://dx.doi.org/10.1023/A:1023331212247

Wai Kong Cheung, A. (2011). Do Stock Investors Value Corporate Sustainability? Evidence from an event study. Journal of Business Ethics, 145-165. http://dx.doi.org/10.1007/s10551-010-0646-3 